\section{Bibliografía referenciada}

1. Nota Informativa MUH (FV),10/2008. Terapia hormonal en la menopausia: Actualización de la información. Disponible en: http://www.aemps.gob.es/informa/notasinformativas/medicamentosUsoHumano/seguridad/2008/NI_2008-16_terapia_hormonal.htm

2. Nota de seguridad MUH (FV), 09/2013. CALCITONINA: SUSPENSIÓN DE LA COMERCIALIZACIÓN DE LOS PREPARADOS INTRANASALES Y RESTRICCIÓN DEL USO DE LOS PREPARADOS INYECTABLES A TRATAMIENTOS DE CORTA DURACIÓN. Disponible en: http://www.aemps.gob. es/en/informa/notasInformativas/medicamentosUsoHumano/seguridad/2013/NI-MUH_FV_092013-calcitonina.htm

3. Nota de seguridad MUH (FV), 2/2014. FINALIZACIÓN DE LA REVISIÓN DEL BALANCE BENEFICIORIESGO DE RANELATO DE ESTRONCIO (OSSEOR®, PROTELOS®): RESTRICCIONES DE USO Disponible en: http://www.aemps.gob.es/informa/notasInformativas/medicamentosUsoHumano/ seguridad/2014/NI-MUH_FV_02-2014-ranelato-estroncio.htm

4. Agencia de Evaluación de Tecnologías Sanitarias (AETS). Instituto de Salud Carlos III - Ministerio de Ciencia e Innovación. IMAZ IGLESIA I. et al. "Análisis coste-utilidad de los tratamientos farmacológicos para la prevención de fracturas en mujeres con osteoporosis en ESPAÑA" IPE 63/2010. Madrid: AETS - Instituto de Salud Carlos III, Diciembre de 2010

5. CatSalut y la Universidad Pompeu Fabra (Centre de Recerca en Economia de la Salut). García Ruiz AJ. et al. Revisión sistemática de evaluaciones económicas de los medicamentos para e tratamiento de la osteoporosis postmenopáusica comercializados en España. Barcelona 2008 Disponible en: http://www20.gencat.cat/docs/salut/Minisite/catsalut/Proveidors_professionals/ medicaments_farmacia/farmaeconomica/CAEIP/informes_dictaments/osteoporosis/osteoporosis.informe.es.2008.pdf

6. Osteoporosis: Diagnosis, Treatment and Fracture Prevention. Guidelines and Protocols Advisory Committee. British Columbia Medical Association; 2012 Victoria BC. Disponible en: http://www. bcguidelines.ca/guideline_osteoporosis.html

7. NICE technology appraisal guidance 160 (amended) Alendronate, etidronate, risedronate, raloxifene and strontium ranelate for the primary prevention of osteoporotic fragility fractures in postmenopausal women (amended). 2011. Disponible en: http://publications.nice.org.uk/alendronateetidronate-risedronate-raloxifene-and-strontium-ranelate-for-the-primary-prevention-ta160

8. NICE technology appraisal guidance 161 (amended) Alendronate, etidronate, risedronate, raloxifene, strontium ranelate and teriparatide for the secondary prevention of osteoporotic fragility fractures in postmenopausal women (amended). 2011. Disponible en: http://publications.nice. org.uk/alendronate-etidronate-risedronate-raloxifene-strontium-ranelate-and-teriparatide-forta161

9. Comité de expertos de la SEIOMM. Guías de práctica clínica en la osteoporosis posmenopáusica glucocorticoidea y del varón. Sociedad Española de Investigación Ósea y del Metabolismo Mineral. Rev Osteoporos Metab Miner 2009 1;1:53-60

10. Grupo de trabajo de la Guía de Práctica Clínica sobre Osteoporosis y Prevención de Fracturas por Fragilidad. Guía de Práctica Clínica sobre Osteoporosis y Prevención de Fracturas por Fragilidad. Plan de Calidad para el Sistema Nacional de Salud del Ministerio de Sanidad, Política Social e Igualdad. Agència d'Informació, Avaluació i Qualitat en Salut (AIAQS) de Cataluña; 2010. Guías de Práctica Clínica en el SNS: AATRM № 2007/02.

11. AACE Osteoporosis Task Force. American Association of Clinical Endocrinologists Medical Guidelines for Clinical Practice for de diagnosis and treatment for menopausal osteoporosis. Endocr Pract 2010; 16 (Supp 3).

12. Kanis JA, \& McCloskey EV, Johansson H, Cooper C, Rizzoli, Reginster JY. European guidance for the diagnosis and management of osteoporosis in postmenopausal women. Osteoporos Int 2013;24:23 57

13. Gauthier K, Bai A, Perras C, Cunningham J, Ahuja,T, Richter T, Kovacs, C. Denosumab, Raloxifene and Zoledronic Acid for the Treatment of Postmenopausal Osteoporosis: Clinical Effectiveness and Harms [Internet]. Ottawa: Canadian Agency for Drugs and Technologies in Health; 2012 (Rapid Response Report: Systematic Review).

14. Mendoza N, Sanchez-Borrego R, Villero J, Baro F, Calaf J, Cancelo MJ et al. 2013 Up-date of the consensus statement of the Spanish Menopause Society on postmenopausal osteoporosis. Maturitas 76 (2013) 99- 107

15. Rosen HN, Drezner MK. Overview of the management of osteoporosis in postmenopausal women. [internet]. Walthman(MA): UpToDate, Jan 2014. [acceso el 21/4/14]. Disponible en: http://www. uptodate.com.mergullador.sergas.es:2048/contents/overview-of-the-management-of-osteoporosis-in-postmenopausal-women?source=search_result\&search=0steoporosis\&selectedTitle=1 $\% 7 E 150 \#$ H8

16. Perez LI, Alonso A, Roig D, García A, Guañabens N, Peris P, et al. Actualización 2011 del consenso Sociedad Española de Reumatología de osteoporosis. Reumatol Clin. 2011;7(6):357-379

17. American Association of Oral and Maxillofacial Surgeons. Position Paper on Medication- Related Osteonecosis of the Jaw- 2014 Update. J Oral Maxillofac Surg. In Press.

18. Nota de seguridad MUH (FV), 04/2011. BISFOSFONATOS Y RIESGO DE FRACTURAS ATÍPICAS DE FÉMUR. Disponible en: http://www.aemps.gob.es/informa/notasInformativas/medicamentosUsoHumano/seguridad/2011/NI-MUH_04-2011.htm

19. Becker CB, Cohen A. Evaluation and treatment of premenopausal osteoporosis. [internet] Walthman(MA): UpToDate, Mar 2014. [acceso el 12/5/14]. Disponible en: http://www.uptodate.com.mergullador.sergas.es:2048/contents/evaluation-and-treatment-of-premenopausalosteoporosis?source=search_result\&search=0steoporosis+premenopausica\&selectedTitle=1\% $7 \mathrm{E} 150$

20. Coello JA, Lledó E. Recomendaciones en la prevención y manejo de la osteonecrosis maxilar por bisfosfonatos. Sociedad Española de Epidemiología y Salud Publica Oral. Abril 2013.

21. Sosa M , Gómez de Tejada MJ, et al. Osteonecrosis de los maxilares:Documento de consenso Rev Osteoporos Metab Miner 2009 1;1:41-51 41

\section{Bibliografía consultada}

(Por fecha de publicación, de más reciente a más antigua)

Kanis JA, \& McCloskey EV, Johansson H, Cooper C, Rizzoli, Reginster JY. European guidance for the diagnosis and management of osteoporosis in postmenopausal women. Osteoporos Int 2013;24:23-57

Compston J, Bowring C, Cooper A, Cooper C, Davies C, Francis R, Kanis JA, Marsh D, McCloskey EV, Reid DM, Selby P. Diagnosis and management of osteoporosis in postmenopausal women and older men in the UK: National Osteoporosis Guideline Group (NOGG) update 2013. Maturitas 2013;75:392- 396

Cummings SR, Cosman F, Eastell R, Reid IR, Mehta M, Lewiecki EM. GoalDirected Treatment of Osteoporosis. Journal of Bone and Mineral Research 2013;28(3):433-438

Silverman S, Christiansen C. Individualizing osteoporosis therapy. Osteoporos Int 2012;23:797-809

Khosla S, Bilezikian JP, Demster DW et al. Benefits and Risks of Biphosphonate Therapy for Osteoporosis. J Clin Endocrinol Metab, 2012, 97 (7) 2272-2282

Pérez Edo LI, Alonso Ruiz A, Roig Vilaseca D, García Vadillo A, et al. Actualización 2011 del consenso Sociedad Española de Reumatología de osteoporosis. Reumatol Clin. 2011;7(6):357-379

Caeiro-Rey JR, Etxebarria-Foronda I, Mesa-Ramos M. Fracturas atípicas relacionadas con el uso prolongado de bifosfonatos. Estado de la situación. Rev Esp Cir Ortop Traumatol. 2011;55(5):392-404

American Association of Oral and Maxillofacial Surgeons. Position Paper on Biphosphonate-Related Osteonecosis of the Jaw-2009 Update. J Oral Maxillofac Surg 2009; 67 (5 Suppl): 2-12

Sosa Henríquez M, Gómez de Tejada Romero MJ, Bagán Sebastián JV et al. Osteonecrosis de los maxilares: Documento de consenso. Rev Osteoporos Metab Miner 2009 1; 1:41-51

Smith MR, Egerdie B, Hernández Toriz NN, Feldman R, Tammela TL, Saad F et al. Denosumab in men receiving androgen-deprivation therapy for prostate cancer. N Engl J Med 2009; 361:745-755

Hans DB, Sepherd JA, Schwartz EN, Reid DM, Blake GM, Forham JN et al. Peripheral dual-energy $\mathrm{X}$-ray absorptiometry in the management of osteoporosis: the 2007 ISCD Official Positions. J Clin Densitom 2008; 11:163-187.

Ebeling PR. Clinical practice. Osteoporosis in men. N Engl J Med 2008; 358:1474-1482.

González Macías J, Guañabens Gay N, Gómez Alonso C, del Río Barquero R, Muñoz Torres M, Delgado M et al. Guía de práctica clínica en la osteoporosis postmenopáusica, glucocorticoides y del varón. Sociedad Española de Investigación Ósea y Metabolismo Mineral. Rev Clin Esp 2008; 208:1-24

Khosla S, Burr D, Cauley J, et al. Biphosphonate -associated osteonecrosis of the jaw: report of a task force of the Amercian Society for Bone and Mineral Research. J Bone Miner Res 2007; 22: 1479-1491

Saag KG, Shane E, Boonen S, Marin F, Donley DW, Taylor KA et al. Teriparatide or alendronate in glucocorticoid-induced osteoporosis. N Engl J Med 2007; 357:2028-2039.

Eastell R, Hannon R. Long-term effects of aromatase inhibitors on bone. J Steroid Biochem Mol Biol 2005; 95:151-154

Guañabens N, Monegal A. Osteoporosis asociada al trasplante. En: Riancho JA y González J, eds. Manual Práctico de Osteoporosis y Metabolismo Mineral. Jarpyo Editores, 2004; 279-284.

Bianchi ML. Osteoporosis in children and adolescents. Bone 2007; 41:486-495

Johnell 0 , de Laet C, Johansson H. Melton LJ. Oral corticosteroids increase fracture risk independently of BMD. Osteoporos Int 2002; 13:S14

Monegal A, Navasa M, Guañabens N, Peris P, Pons F, Martínez de Osaba $\mathrm{MJ}$ et al. Bone disease after liver transplantation: A long-term prospective study of bone mass changes, hormonal status and histomorphometric characteristics. Osteopor Int 2001; 12:484-492

Van Staa TP, Leufkens HGM, Abenhaim L, Zhang B, Cooper C. Use of oral corticoids and risk of fractures. J Bone Miner Res 2000; 15:993-1000 Townsend MF, Sanders WH, Northway RO, Graham SD Jr. Bone fractures associated with luteinizing hormone releasing used in the treatment of prostate carcinoma. Cancer 1997; 79:545-550. 